\title{
Banks and Governments: An Arial View
}

Anna Gelpern

This paper can be downloaded free of charge from:

https://scholarship.law.georgetown.edu/facpub/1293

http://ssrn.com/abstract=2342202

This open-access article is brought to you by the Georgetown Law Library. Posted with permission of the author. Follow this and additional works at: https://scholarship.law.georgetown.edu/facpub

Part of the Banking and Finance Law Commons, Finance Commons, and the Legal Theory Commons 
Version $07 / 16 / 13$

\title{
Banks and Governments: An Arial View
}

Anna Gelpern ${ }^{1}$

\begin{abstract}
This chapter of the Liber Amicorum considers the relationship between banking and sovereign debt crises since the 1980s.
\end{abstract}

\section{Introduction: Font Matters}

1.1 It has been a distinctive yet unremarked upon pattern: each time European officials unveil bold new measures to end the Crisis, a few draft pages in Arial 12 font appear on SSRN. Within hours, the draft is downloaded thousands of times, sending ripples across the blogosphere before lodging in a pink paper column and in the side of said officials. The authors, Lee Buchheit and Mitu Gulati, make roughly the same argument each time: policy makers have three to five options to solve the problem before them. One of these does more harm than good. Coincidentally, it is the chosen one. The draft then charts a path out of the hole. Sometimes officials take the path—eventually ${ }^{2}$-at other times, they keep digging.

1.2 The duo's latest intervention followed the launch of a program for Cyprus. ${ }^{3}$ The Cypriot banking system was eight times the size of the island's economy and tottering on the brink from exposure to Greece. As a condition of financing the government, Europe insisted that bank depositors pay a burden-sharing "tax." The tax would contain the crisis in the banking sector and spare the holders of government bonds. The announcement would showcase Europe's commitment to share losses with private creditors, and to break the bond between banks and national governments.

1.3 It took three pages in Lee Buchheit's trademark font to demolish the plan and lay out an alternative. What came to be called "the botched Cyprus bailout" was doomed from the start: after paying the deposit tax, people would have pulled the rest of their savings, brought down the banking system and forced the government to intervene on a much larger scale. Buchheit and Gulati instead proposed to extend uninsured deposits over EUR100, 000 into five and ten-year certificates of deposit, and to reschedule EUR8.2 billion in government debt. This combination would have filled more than half of the program financing gap without touching the insured depositors.

\footnotetext{
${ }^{1}$ Georgetown Law and Peterson Institute for International Economics; portions of this contribution have appeared in Foreign Policy Association Great Decisions 2011 and on CreditSlips.org. I am grateful to the many colleagues who have commented on early versions of this paper, to the editors of this volume, and to Will Chamberlain for valuable research assistance.

${ }^{2}$ See, e.g., Jeromin Zettelmeyer et al., The Greek Debt Exchange: An Autopsy 33 (September 11, 2012) (working paper) http://papers.ssrn.com/sol3/papers.cfm?abstract_id=2144932; Lee C. Buchheit \& G. Mitu Gulati, How to Restructure Greek Debt 7-10 (May 7, 2010) (working paper).

${ }^{3}$ See Lee C. Buchheit \& G. Mitu Gulati, Walking Back from Cyprus (March 8, 2013) (working paper) http://papers.ssrn.com/sol3/papers.cfm?abstract_id=2235359.
} 
1.4 Their prescription flowed from the insight that governments and financial systems are communicating vessels: strength or weakness in one flows to the other, and back. My essay elaborates the implications of this insight. I consider the bank-government link in recent financial crises. It is far from unique to Europe, though it does not always result in feedback effects, or the "doom loop," which has made headlines of late. As capital movements have become more rapid and global, the abiding connection between banks and governments has turned destructive. The policy goal is to reduce the risk of destruction and harness the connection in the name of financial stability. In conclusion, I suggest several policy implications and avenues for further research.

\section{Far from Europe}

1.5 On January 27, 2011, Standard \& Poor's downgraded Japan's government debt, which then stood at nearly double the size of the Japanese economy. ${ }^{4}$ The Prime Minister apparently learned about the downgrade from a foreign journalist. His flub instantly became iconicbut it was also overblown: the downgrade had little meaning for most of Japan's creditors. For regulated domestic financial institutions, holding almost $70 \%$ of Japanese government bonds, for government pension funds, and for the Japanese central bank, there were few practical consequences from the S\&P pronouncement. At the extreme, the value of the debt to these creditors was a function of regulatory say-so, and their prospects of repayment a function of domestic politics. Only foreigners, holding just over $5 \%$, might have had reason to listen to S\&P. ${ }^{5}$

1.6 This anecdote is at once happy, sad, and symptomatic of an old relationship at the heart of modern finance. It is about banks and governments, which are both inseparable and doomed to bring each other down. On the bright side, they are each other's indispensable safety net. On the dark side, government debt default can ravage financial systems, and banking crises can bring down governments.

1.7 Until recently, bank and government debt problems were seen as related, but distinct. Banking crises were bad for the economy and hence for public finances. ${ }^{6}$ Rulers running

\footnotetext{
${ }^{4}$ Japan (Unsolicited Rating), STANDARD \& POOR's, http://www.standardandpoors.com (Apr. 2, 2011) (indicating the Jan. 27, 2011 credit rating downgrade to AA-); see International Monetary Fund [IMF], Japan: Staff Report for the 2010 Article IV Consultation, at 27, 32, IMF Country Report No. 10/211 (July, 2010); Lindsay Whipp \& Mure Dickie, S\&P downgrades Japan on debt worries, FINANCIAL TIMES, Jan. 27, 2011, available at http://www.ft.com/cms/s/0/095efb70-29f3-11e0-997c-00144feab49a.html\#axzz1l5eYizo3.

${ }^{5}$ Whipp \& Dickie, supra note 4; See Ministry of Finance of Japan, Debt Management Report 2010, Ch. 3 at 20, available at http://www.mof.go.jp.

${ }^{6}$ See, e.g., CARMEn M. Reinhart \& Kenneth S. Rogoff, This Time Is Different: EIGHT Centuries Of Financial Folly 141-73 (2009); Ben S. Bernanke, Nonmonetary Effects of the Financial Crisis in the Great Depression, 73 AM. ECON. REV. 257, 263-67 (1983).
} 
short on funds have turned to banks since time immemorial, which did not imply the death of regulated institutions, nor the start of a self-destructive spiral. Bank and government debt crises traveled along distinct paths, required different prophylactic measures ex ante and different solutions ex post. For modern banks, solvency regulation has been the principal bulwark against failure; resolution the principal way to limit collateral damage from failure. For governments, fiscal fiscal prudence has been the accepted prophylactic; adjustment (belttightening) and debt restructuring, the standard solutions.

1.8 The five case studies below reveal the blurry boundary between bank and government crises. In Asia, Europe, and the Americas, events now known as either banking or government debt crises often had elements of both. Some could have gone either way; policy and political choices determined their path. In all cases governments were as indispensable for resolving banking crises, as banks were for resolving sovereign debt crises. More recently, the feedback loop between bank and sovereign distress appears to have intensified, prompting calls for radical measures to break the bank-government link. Some of the measures proposed so far may adjust, elaborate, or displace the link; none would break it.

\section{Banks or Governments}

1.9 Accounts of banking crises start with a credit boom, where private institutions (perhaps operating under loose monetary conditions) make imprudent loans financed by fragile shortterm borrowing. ${ }^{7}$ An economic downturn might deliver a shock to bank assets; market conditions might make it impossible for banks as a group to roll over maturing liabilities. Policy makers then face a choice: to let private losses fall where they may, to redistribute them among private actors, to absorb some losses on behalf of their taxpayers, or to make them a problem for another government.

\section{A. $\quad$ Korea 1997}

1.10 Korea's was a traditional banking crisis story. Its banks had borrowed from abroad to finance risky domestic corporate loan portfolios. When the currency crisis in Thailand and Indonesia spread to Korea in late 1997, the banks could not roll over their short-term debts to foreign financial institutions. As they repaid these foreign loans, the banks drained Korea's hard currency reserves. A blanket government guarantee of all bank liabilities failed to stem the outflow. At year-end, finance officials in Europe, Japan, and the United States had to cajole their banks to renew loans to Korean banks to avoid imminent default.

\footnotetext{
${ }^{7}$ REINHART \& Rogoff, supra note 6 at 144-45.
} 
1.11 By then, more than half of all Korean banks were operating with insufficient capital. ${ }^{8}$ At the height of the crisis in 1998, close to a third of all Korean firms were insolvent; more than half were illiquid. ${ }^{9}$ Also in 1998, foreign lenders agreed to a formal restructuring of their claims on Korean banks. In exchange, they got debt guaranteed by the government of Korea. By October 2000, the government absorbed resolution costs to the tune of $22 \%$ of GDP. ${ }^{10}$

1.12 Despite this extraordinary spending, Korea's government exited the crisis with debt at $18 \%$ of GDP: double the pre-crisis level of $9 \%$, but still very low by international standards. ${ }^{11}$ The Korean banking crisis did not bring down public finances in part because government debt was low at the outset, the size of the banking sector was manageable in retrospect, ${ }^{12}$ and the economy's growth potential was high. ${ }^{13}$

1.13 The Asian financial crisis is usually described as originating in the private corporate and financial sectors. Poor lending and borrowing decisions by banks left countries like Korea exposed to external shocks that demanded government intervention. On the other hand, it is also true that bank lending and borrowing practices channeled government economic policy. ${ }^{14}$ Although bank debts did not bankrupt the Korean national treasury, they did nearly drain the central bank's foreign exchange reserves. ${ }^{15}$ Breathing space for the eventual restructuring came courtesy of foreign governments using "moral suasion" to maintain their

\footnotetext{
${ }^{8}$ Ajai Chopra et al., From Crisis to Recovery in Korea: Strategy, Achievements, and Lessons 38 (Working Paper of the International Monetary Fund, No. 01/154, 2001), available at http://www.imf.org/external/pubs/ft/wp/2001/wp01154.pdf.

${ }^{9}$ Stijn Claessens et al., Corporate Distress in East Asia, Public Policy fOR THE Private Sector (World Bank, Washington, D.C.), January 1999, at 1 tbl.1, available at http://siteresources.worldbank.org/EXTFINANCIALSECTOR/Resources/282884-1303327122200/172claes.pdf.

${ }^{10}$ Chopra et al., supra note 6, at 44.

${ }^{11}$ World Economic Outlook Database, INT'L MoneTARY Fund (April 2013), http://www.imf.org/external/pubs/ft/weo/2013/01/weodata/weoselgr.aspx (select "Advanced Economies" country group; then click "Clear All" and select "Korea"; then select "General government gross debt - Percent of GDP"; select "Start Year" of 1995 and "End Year" of 2000; then click "Prepare Report").

${ }^{12}$ Commercial bank assets stood over 150\% of GDP in Korea in 1996, compared to $136 \%$ in the European Union at the time. Carl-Johan Lindgren, et al., Financial Crisis and Restructuring: Lessons from Asia 11, 13 box 3 (1999), available at http://www.imf.org/external/pubs/ft/op/opfinsec/op188.pdf. By 2011, bank assets in Europe were closer to $300 \%$ of GDP, and exceeded $700 \%$ in Cyprus and Ireland. Stefano Borgioli Et al., Financial Stability Analysis - Insights Gained From Consolidated Banking Data For the EU 15 chart 1, available at http://www.ecb.int/pub/pdf/scpops/ecbocp140.pdf; Int'I Monetary Fund, European Union: Publication of Financial Assessment Porgram Documentation 6 (IMF Country Report No. 13/67, Mar. 2013) available at http://www.imf.org/external/pubs/ft/scr/2013/cr1367.pdf.

${ }^{13}$ See Chopra et al., supra note 6, at 76-77 \& tbl.10. See also Ashoka Mody \& Damiano Sandri, The Eurozone Crisis: How Banks and Sovereigns Came to be Joined at the Hip, 27 ECON. POL'Y 199, 206 (2012) (weak growth prospects can intensify banking crises)

${ }^{14}$ See Chopra, supra note 6, at 8-10.

${ }^{15}$ See Mark Allen, et al., A Balance Sheet Approach to the Financial Crisis 17-18 (IMF Working Paper 02/210, December 2002) available at http://www.imf.org/external/pubs/ft/wp/2002/wp02210.pdf. See also PAUL BLUSTEIN, The ChASTENING 124-27 (2001).
} 
own banks' exposure to Korea. ${ }^{16}$ The story shifts easily from one of a private sector crisis and exceptional public intervention to one of long-term symbiosis and mutual assured destruction. It is also a transnational story, where governments across jurisdictions leverage their relationships with regulated institutions for the sake of financial stability.

1.14 A decade on, Korea's ability to cushion the fall of its banks looked unusual, almost quaint.

\section{B. $\quad$ Iceland 2008}

1.15 Between 2003 and 2007, Iceland - a country of about 300,000 inhabitants and an economy of about $\$ 12$ billion - transformed from a fishing hub into a major international financial center. It had five main commercial banks, of which the three largest (accounting for $90 \%$ of the banking system) borrowed tens of billions of dollars short-term on the international capital markets. Unchecked by regulators, they amassed speculative and illiquid investments abroad. In 2004-2006, these banks sought to diversify their funding sources and expand their retail deposit base. ${ }^{17}$ Buoyed by permissive cross-border expansion rules in the European Economic Area, ${ }^{18}$ they attracted deposits from a wide range of sources, including local governments in Britain and retirees in the Netherlands; however, the bulk of Icelandic bank funding still came from the wholesale capital markets. Bank assets grew from roughly equal to over ten times the size of the economy in just three years. More than half were abroad, but even assets in Iceland were nearly four times the size of the economy on the eve of the crisis. Over $80 \%$ of bank liabilities and just under $80 \%$ of their assets were denominated in foreign currencies. ${ }^{19}$

1.16 When global financial markets collapsed in the fall of 2008 , the currency fell by $40 \%$, the banks could no longer refinance their debts, and were taken over by the government beginning October 6 . The legislature enacted emergency measures authorizing the government to "ring fence" domestic assets and liabilities of the banking system, and retroactively granted depositors preference over other bank creditors. Fearing losses to U.K. depositors, the U.K. government famously invoked antiterrorism legislation to freeze

\footnotetext{
${ }^{16}$ See Paul Blustein, The Chastening 192-202 (2001).

${ }^{17}$ See Int'I Monetary Fund, Iceland: 2008 Article IV Consultation 4 box 1 (IMF Country Report No. 08/367, December 2008), available at http://www.imf.org/external/pubs/ft/scr/2008/cr08367.pdf.

${ }^{18}$ House of Commons Treasury Committee, Banking Crisis: The impact of the failure of the Icelandic banks 11 (April 4, 2009), available at http://www.publications.parliament.uk/pa/cm200809/cmselect/cmtreasy/402/402.pdf. EEA comprises EU member states plus Iceland, Norway and Liechtenstein.

${ }^{19}$ See Int'I Monetary Fund, Iceland: 2008 Article IV Consultation 3, 28 tbl.3 (IMF Country Report No. 08/367, December 2008), available at http://www.imf.org/external/pubs/ft/scr/2008/cr08367.pdf.
} 
Icelandic bank assets in the United Kingdom, accelerating wholesale collapse of the banking sector in Iceland. ${ }^{20}$ Iceland's government fell shortly thereafter.

1.17 With the IMF's blessing, the authorities imposed capital controls and proceeded to restructure the banks. Some smaller ones were sold or liquidated; the largest were split along national lines. Three new banks established with government capital got the domestic assets and domestic liabilities; the old failed banks retained the foreign assets and liabilities. Domestic deposits received a blanket government guarantee. Some foreign creditors of the old banks were able to swap their debt into new bank equity. Government debt went from $30 \%$ to $120 \%$ of GDP, mostly owing to economic contraction from the crisis. ${ }^{21}$ Net direct costs of bank restructuring have been estimated at about $20 \%$ of GDP, attributable in important part to central bank financing for the banking system on the eve of the crisis. ${ }^{22}$ Negotiations over allocating the losses continue five years later; some foreign creditors stand to lose nearly all of their investment. ${ }^{23}$

1.18 In retrospect, the fall looks inevitable. Iceland started out with low government debt; but no government can guarantee liabilities remotely approaching ten times the size of its economy, and no central bank can hold enough foreign currency to finance capital outflows on the scale threatening Iceland. When the government could not compensate everyone, it chose to pay its own citizens ahead of foreign creditors, including ordinary Europeans who put money in Iceland's banks.

1.19 The U.K. and Dutch governments were unwilling to see their nationals lose hard-earned savings in Iceland. They compensated their depositors, and sued Iceland's government for compensation — a bid to turn bank debt (deposits) into sovereign debt.

\footnotetext{
${ }^{20}$ See Althingi Special Investigation Commission, Causes of the Collapse of the Icelandic Banks - Responsibility, Mistakes, and Negligence 89 (April 12, 2010) available at http://www.rna.is/media/skjol/RNAvefurKafli21Enska.pdf; House of Commons Treasury Committee, Banking Crisis: The impact of the failure of the Icelandic banks 9 १ $41-42$ (April 4, 2009), available at http://www.publications.parliament.uk/pa/cm200809/cmselect/cmtreasy/402/402.pdf.

${ }^{21}$ Int'I Monetary Fund, Iceland: 2010 Article IV Consultation 33 tbl.7 (IMF Country Report No. 10/305, October 2010) available at http://www.imf.org/external/pubs/ft/scr/2010/cr10305.pdf; Int'l Monetary Fund, Iceland: Ex Post Evaluation of Exceptional Access Under the 2008 Stand-by Arrangement 14 available at http://www.imf.org/external/pubs/ft/scr/2012/cr1291.pdf.

${ }^{22}$ Int'I Monetary Fund, Iceland: 2010 Article IV Consultation 33 tbl.7 (IMF Country Report No. 10/305, October 2010) available at http://www.imf.org/external/pubs/ft/scr/2010/cr10305.pdf; Int'I Monetary Fund, Iceland: Ex Post Evaluation of Exceptional Access Under the 2008 Stand-by Arrangement 14 available at http://www.imf.org/external/pubs/ft/scr/2012/cr1291.pdf. See also Friõrik Már Baldursson, Iceland's programme with the IMF 2008-11, Vox (Nov. 8, 2011) http://www.voxeu.org/article/iceland-s-programme-imf-2008-11. ${ }^{23}$ International Monetary Fund, Iceland: Ex Post Evaluation of Exceptional Access Under the 2008 Stand-by Arrangement, IMF Country Report No. 12/91 April 2012, pp.13-14, 19. Available at http://www.imf.org/external/pubs/ft/scr/2012/cr1291.pdf; see also Richard Milne, Iceland's Creditors Braced for Losses, Financial Times, May 2, 2013, http://www.ft.com/intl/cms/s/0/298407e8-b19a-11e2-b32400144feabdc0.html\#axzz2VNIxdAIC.
} 
1.20 In 2013, the European Free Trade Area court rebuffed their claims. ${ }^{24}$ It ruled that Iceland's treaty obligations were limited to establishing a deposit insurance scheme; funding the scheme was another matter. The upshot of the decision was that Icelandic banks had every right to take deposits across Europe with a private and utterly underfunded deposit insurance scheme; creditors took the risk and paid the price. ${ }^{25}$ While many observers decried the court's formalistic approach, ${ }^{26}$ others greeted the decision as a strike against bailouts. ${ }^{27}$ From now on, they said, private creditors would have to live with the consequences of their investment decisions.

1.21 It was a stretch to describe the ruling as a victory for private responsibility. Although some bank creditors will surely suffer large losses, this group of depositors was rescued by a different cast of government characters. Rather than adding to Iceland's debt stock, the liabilities migrated from Iceland's onto U.K. and Dutch government books.

1.22 In late 2008, Iceland seemed like an anomaly - its private banking sector had grown so monstrously large so quickly that it simply swallowed up the country, government and all. It did so using a quirk in the European treaty framework, which did not require countries to fund or backstop deposit insurance, and which was subsequently validated by a court's reading of the treaties.

1.23 The dramatic details obscure the ways in which Iceland was rather ordinary. Outsize banking sectors have become the norm in Europe, with assets at more than three times the size of national economies on average. ${ }^{28}$ Offshore financial centers like Cyprus and Switzerland have banking sectors far bigger than the average, ${ }^{29}$ Luxembourg's banks dwarf the rest at

\footnotetext{
${ }^{24}$ See Case E-16/11, EFTA Surveillance Authority v. Iceland, 2013 WestlawNext 9178 (Jan 28, 2013).

${ }^{25}$ See Case E-16/11, EFTA Surveillance Authority v. Iceland, 2013 WestlawNext ๆ 19-23 (Jan 28, 2013).

${ }^{26}$ See, e.g., Tim Young, Editorial, EFTA Court's Icesave Ruling Leaves European Deposit Insurance in Tatters, CENTRAL BANKING, Jan. 31, 2013, http://www.centralbanking.com/central-banking/opinion/2240651/opinion-efta-courtsicesave-ruling-leaves-european-deposit-insurance-in-tatters.

${ }^{27}$ See, e.g., Editorial, Saga ends with Icesave Redemption, FINANCIAL TIMES, Jan. 29, 2013, http://www.ft.com/intl/cms/s/0/78b96684-6a21-11e2-a80c-00144feab49a.html\#axzz2VNIxdAlC.

${ }^{28}$ See European Central Bank, EU Banking Structures 10 chart 3 (September 2010) available at http://www.ecb.int/pub/pdf/other/eubankingstructures201009en.pdf

${ }^{29}$ Compare Aggregated balance sheet of euro area monetary financial institutions, excluding the Eurosystem: December 2012, EUROPEAN CENTRAL BANK, http://www.ecb.int/stats/money/aggregates/bsheets/html/outstanding_amounts_2012-12.en.html (last visited June 8, 2013) (showing that Cypriot Banks held total assets of 128.1 billion Euros at the end of 2012) and Swiss National Bank, Monthly Bulletin of Banking Statistics 28 (February 2013) (showing that Swiss banks held total assets of 2.83 trillion Swiss Francs) with International Monetary Fund, World Economic Outlook Database, April 2013 (showing that Cyprus' 2012 GDP was 14.8 billion euros and Switzerland's 2012 GDP was 548 billion Swiss Francs.)
} 
nearly twenty times the size of the economy. ${ }^{30}$ These are products of economic policy choice and regulation as much or more than they are market mutations. Similarly, while Iceland's deposit insurance scheme might seem laughable in retrospect, few funded schemes can withstand complete collapse of the banking system. And as the EFTA court noted, once the system collapses, governments choose how they go about restructuring, even if it means stiffing the foreigners in favor of their own voters. The fact that governments will rescue their people and institutions, but try to stick other governments with the bill is also hardly unusual. Crises from Mexico in 1982 to the United States in 2008 saw policy makers debating whether and how to push losses from their financial institutions onto other people's taxpayers. $^{31}$

\section{Governments or Banks}

1.24 It generally takes a big banking sector to bring down a national treasury. Loss on relatively small holdings of public debt can wipe out bank equity. This is because compared to other firms, banks are thinly capitalized. ${ }^{32}$ If banking system capital is at $8 \%$ of risk-weighted assets, a default on government debt, or even a big drop in its value, can quickly leave the system undercapitalized and many banks insolvent.

1.25 Government debt stood at over $10 \%$ of banking system assets in six out of the 24 highincome countries last surveyed by the IMF, with Japan leading the pack at nearly $25 \%$ and Italy at nearly $15 \%$, in line with Greece before its debt restructuring. ${ }^{33}$ The United States was not one of the six, but would easily make the list if bank holdings of Government Sponsored Enterprise debt were included. ${ }^{34}$ All U.S. government obligations stood at more than $13 \%$ of the assets in the U.S. banking system in March 2013. In developing countries where capital

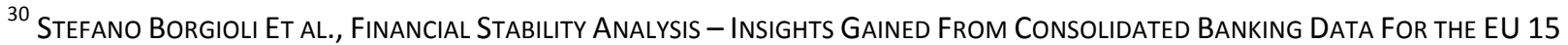
chart 1 (2013) available at http://www.ecb.int/pub/pdf/scpops/ecbocp140.pdf

${ }^{31}$ See Report of Anton R. Valukas, Examiner at 703-10, In re Lehman Bros. Holdings Inc., 439 B.R. 811 (S.D.N.Y. 2010) (No. 08-13555(JMP)) (discussing Lehman); Congressional Oversight Panel, June Oversight Report: The AIG Rescue, Its Impact on Markets, and the Government's Exit Strategy 92-93 (June 10, 2010) (discussing AIG).

32 See generally Anat Admati and Martin Hellwig, The Bankers' New Clothes (Princeton: Princeton University Press 2013) (discussing why banks have higher leverage than other firms).

${ }^{33}$ See INT'L MONETARY FUnd, GLOBAL FINANCIAL STABILITY REPORT 133 fig.3.7 (2013), available at http://www.imf.org/External/Pubs/FT/GFSR/2013/01/pdf/text.pdf. See also Serkan Aslanalp and Takahiro Tsuda, Tracking Global Demand for Advanced Economy Sovereign Debt 32 fig.15 (Int'l. Monetary Fund, Working Paper No. 12/284, December 2012) available at http://www.imf.org/external/pubs/ft/wp/2012/wp12284.pdf 32 fig.15.

${ }^{34}$ FDIC statistics for Government-Sponsored Enterprises cover the Federal National Mortgage Association, the Federal Home Loan Mortgage Corporation, the Federal Home Loan Bank System, the Farm Credit Banks, the Banks for Cooperatives, the Federal Agricultural Mortgage Corporation, the Student Loan Marketing Association, the College Construction Loan Insurance Association, and any of their affiliated or member institutions, and any other Government-sponsored enterprise as designated by the Secretary of the Treasury. See 12 U.S.C. § 1828(s)(5) (2013) (citing Financial Institutions Reform, Recovery, and Enforcement Act (FIRREA) of 1989, sec. 1404(e)(1)(A), Pub. L. No. 101-73, 103 Stat. 183). Investors have long bought the debt of GSE's as a proxy for the debt of the Federal Government even before the takeovers of Fannie Mae and Freddie Mac in 2008.
} 
market is shallow and lending to the private sector limited, government securities may be the only game in town.

1.26 Bank holdings of government debt often increase in the run-up to financial crisis. ${ }^{35}$ Like other investors, banks may see government debt as a safe haven in times of market turbulence and risk aversion; they may also come under pressure from the government to act as its lenders of last resort when all other creditors have left. For example, U.S. bank holdings of U.S. Treasury securities nearly doubled between 2008 and 2010 according to Federal Reserve data. Portuguese bank lending to the Portuguese government more than doubled in the two years preceding its turn to the IMF. ${ }^{36}$

1.27 Regulation and supervision can help obscure — or soften — the impact of public debt problems on the financial sector. Where they applied in ordinary times, borrower concentration limits and activities restrictions might be suspended; asset values might perk up from a newly discovered accounting treatment; and wafer-thin capital cushions may be deemed good enough under the circumstances.

1.28 Argentina's last crisis offers a particularly rich case study of government debt in the banking system, and the way in which direct financial involvement by the government can interact with regulation on bank balance sheets.

\section{A. Argentina 2001}

1.29 To most outside observers, Argentina's government debt default in late 2001 subsumed and overshadowed its banking crisis. Quite apart from their exposure to sovereign credit risk, banks were vulnerable to the effects of economic contraction and currency depreciation: if the peso's 1:1 peg to the U.S. dollar broke down, bank borrowers' wealth would shrink, and their mammoth books of dollar loans would go into default. But the government presented a distinct source of danger for the banks.

1.30 At the height of the crisis, Argentina's public debt ratios were several times the size of Korea's or Iceland's. ${ }^{37}$ Despite a succession of bank runs in the year before default, the government relied on domestic banks and pension funds, along with funding from the IMF,

\footnotetext{
${ }^{35}$ Serkan Arslanalp \& Takahiro Tsuda, Tracking Global Demand for Advanced Economy Sovereign Debt 31-32 \& fig.14-15 (IMF Working Paper 12/284, December 2012) available at http://www.imf.org/external/pubs/ft/wp/2012/wp12284.pdf.

${ }^{36}$ Banco de Portugal, Statistical Bulletin tbl.B.3.7.1 clmn.11 (May 2013), available at http://www.bportugal.pt/enUS/Estatisticas/PublicacoesEstatisticas/BolEstatistico/Publications/B3.pdf. According to press reports at the time, the turn to the IMF was apparently prompted by something of a buyers' strike among domestic institutions.

${ }^{37}$ See Int'I Monetary Fund, Argentina: 2002 Article IV Consultation (IMF Country Report No. 03/226, July 2003) available at http://www.imf.org/external/pubs/ft/scr/2003/cr03226.pdf.
} 
to fill its growing financing gap. Bank credit to the public sector doubled as foreign creditors ran for the hills, while credit to the private sector shrank. The $\$ 5.1$ billion that Argentina borrowed from the IMF that year helped sustain the wobbling currency peg amid rampant capital flight: domestic depositors moved $\$ 16$ billion offshore; short-term external creditors of the banks pulled another $\$ 13.4$ billion. ${ }^{38}$ Banks' sources of funding shrank, as their vulnerability to government default grew.

1.31 Argentina could have used IMF borrowing to cushion the impact of devaluation and public debt restructuring on local banks. ${ }^{39}$ Instead, it gambled for resurrection, apparently at the banks' expense. By the end of 2001, the government needed bank holidays and capital controls to keep the remaining deposits in the banking system. After default, the government continued to use banks to cushion the effects of the crisis on other parts of the economy: for example, it converted dollar loans and deposits into pesos at asymmetric rates, so that bank owners faced a $40 \%$ gap between their assets and liabilities. It eventually filled the gap with new government bonds, which enjoyed favorable regulatory treatment and were serviced while foreign bonds remained in default. ${ }^{40}$ The approach helped debtors; it also reflected the government's unwillingness to nationalize the banking system when bank owners threatened to walk away.

1.32 In sum, a depression, a currency collapse, and a government debt crisis together helped bring down Argentina's banks. Regulation and supervision allowed the government to finance itself from the banks when no other private creditors would lend to it. On the other hand, more regulatory forbearance and new government debt issued post-default kept the banking system on life support while the economy recovered, until deposits could be freed without risking a run. When the government was ready to restructure its foreign debt, domestic banks that held about half of it helped boost creditor participation.

1.33 In Korea, the government stood behind Korean banks and their foreign creditors. In Iceland and Argentina, foreign creditors of the banks and the sovereign, respectively, absorbed losses from the combined bank-government insolvency. In all cases, loss allocation was an iterative process involving multiple political actors, stretching over multiple regulatory cycles.

\section{B. $\quad$ The Third World Debt Crisis 1982}

1.34 What came to be known as the "Third World debt crisis" of the 1980s could have- but did not—become the "First World banking crisis" to rival the Great Depression. Between August

\footnotetext{
${ }^{38}$ Brad Setser \& Anna Gelpern, Pathways Through Financial Crisis: Argentina, 12 GLOBAL GOVERNANCE 465, 479 (2006); NOURIEL ROUBINI \& BRAD SETSER, BAILOUTS OR BAIL-INS? 8 tbl. 1.1; 131 tbl. 4.3 (2004).

${ }^{39}$ International Monetary Fund, Debt-Related Vulnerabilities and Financial Crises-An Application of the Balance Sheet Approach to Emerging Market Countries 26 (2004)).

${ }^{40}$ NOURIEL ROUBINI \& BRAD SETSER, BaILOUTS OR BAIL-INS?? 272 (2004).
} 
1982 and October 1983, 28 governments from Latin America, Africa, Asia and Eastern Europe suspended payments and initiated rescheduling talks over their obligations to commercial banks in the U.S., the U.K. and Germany, among others. In 1982, when Mexico initiated the wave of suspensions and restructurings, loans to the most heavily indebted governments represented over $130 \%$ of all capital in U.S. banks, $85 \%$ of all capital in British banks, and over $31 \%$ of all capital in German banks. ${ }^{41}$ The nine largest U.S. banks were exposed to the tune of $194 \%$ of their capital; over $44 \%$ for Mexico alone.

1.35 Like other banking crises, this one originated with a credit bubble. The oil price shocks in the 1970s led to spikes in dollar revenues of energy-exporting countries, and a corresponding rise in "petrodollar deposits" in major financial center banks. The banks invested the deposits in high-yielding loans to governments and private sector borrowers in developing countries. In the early 1980s, a global recession and rising interest rates in the United States made it impossible for developing-country borrowers to refinance these dollar debts. At the same time, banks in major financial centers were under stress, their capital worn thin with recession, and their loan-loss provisions too low to absorb the looming defaults.

1.36 Sovereign debtors and their creditors' governments faced a dilemma: if the debtors defaulted or pursued debt principal reduction, major banks in the United States and Europe would have been exposed overnight as insolvent, potentially triggering deposit runs, economic and social dislocation in creditors' countries. If the banks' home governments and principal regulators had pursued early debt restructuring, they would have had to backstop their banks to mitigate the consequences. Instead, the creditors' governments helped broker negotiated arrangements with each debtor, whereby bank syndicates refinanced sovereign debts as if they were dealing with a temporary liquidity problem. The debtors also received financing from multilateral creditors and promised policy reform. Such arrangements had to be renegotiated frequently, adding to the sovereign debt stock: foreign bank claims on the most heavily indebted countries went up by nearly one third between 1982 and 1987, while economic growth stagnated. Over the same period, banks in New York, London and Frankfurt were rebuilding capital and provisions. ${ }^{42}$

1.37 The tide turned in 1989, when the idea that developing-country debt stocks were unsustainable became actionable and politically acceptable: banks could absorb principal write-downs with relatively modest regulatory forbearance. In March of that year, U.S. Treasury Secretary Nicholas F. Brady gave a famous speech where he recognized publicly for the first time that full debt repayment would stunt growth in these debtor countries; this

\footnotetext{
${ }^{41}$ William Cline, International Debt ReEXamined, Tables 2.10-2.12 (1995).

${ }^{42}$ William Cline, International Debt ReEXAmined, 70-71 (1995).
} 
signaled major policy change on loss allocation. ${ }^{43}$ His initiative led to restructuring agreements with substantial principal reduction, led again by Mexico, including the forgiveness in total of some $\$ 60$ billion in debt, ${ }^{44}$ much of which fell on banks and their shareholders. ${ }^{45}$ Debt relief was conditioned on dramatic economic reforms including largescale privatization and liberalization in many developing countries.

1.38 The delay in principal reductions and the resulting long-term costs for debtors' economies was a function of many complex factors. However, there is little doubt that the health of leading international commercial banks was a key factor in treating the crisis as one of temporary borrower illiquidity. The burden of debt distress initially fell on the debtors in the form of higher debt stocks and domestic economic adjustment, and only later on the banks in the form of debt write-offs. As in other crises, loss allocation among banks and governments took multiple iterations ofregulatory forbearance, public financing, and inter-government negotiation.

\section{Back to Europe (The Doom Loop)}

1.39 The Eurozone crisis has made the distinction between banking and public debt crises hard to sustain. The combination of very large national banking sectors, strained fiscal resources, financial integration, and the inability of national governments to print money have made it virtually impossible for member states to contain crises in their banks or limit the impact of government debt distress on the banking systems. ${ }^{46}$ Persistent home bias in sovereign debt holdings helped make national banking systems in the most vulnerable member states especially exposed to their governments' debt distress. ${ }^{47}$ However, banks can fall victim to their sovereigns' debt problems even where they do not hold too much of their government's debt: to the extent markets counted on national governments to back their banks, weak public

\footnotetext{
${ }^{43}$ Nicholas F. Brady, Secretary of the Treasury, Remarks to the Brookings Institution and the Bretton Woods Committee Conference on Third World Debt (March 10, 1989) (transcript available online at http://digitalcollections.library.cmu.edu/awweb/awarchive?type=file\&item=441057).

${ }^{44}$ William Cline, International Debt ReEXAmined 17 (1995).

${ }^{45}$ Ross P. Buckley, The Facilitation of the Brady Plan: Emerging Markets Debt Trading From 1989 to 1993,21 FORDHAM INT'L L.J. 1802, 1804-05 \& n.17.

${ }^{46}$ See e.g., Maurice Obstfeld, Finance at Center Stage: Some Lessons of the Euro Crisis (Working Paper, March 2013) available at http://www.princeton.edu/economics/seminar-schedule-by-prog/macros13/FinanceCenterStage.pdf; Paul De Grauwe, The Governance of a Fragile Eurozone, 45 Australian Economic Review 255 (September 2012); S. Gerlach, A.Schulz, \& G.B.Wolff, Banking and Sovereign Risk in the Euro Area, CEPR DP 7833 (2010); Mody \& Sandri, supra note 13.

${ }^{47}$ See e.g., International Monetary Fund, Greece: Ex Post Evaluation of Exceptional Access Under the 2010 Stand-By Arrangement (June 5, 2013), available at http://www.imf.org/external/pubs/cat/longres.aspx?sk=40639.0 (attributing the delay in Greek debt restructuring partly to Greek bank exposure to their sovereign).
} 
finances showed among other things diminished capacity to support the banking sector. ${ }^{48}$ An early and stark illustration of the loop dynamic came from Ireland.

1.40 At the height of the global financial crisis in 2008, Ireland's financial system buckled under the weight of bad real estate loans. When it collapsed, the system stood at eight times the size of the Irish economy. Partly under external pressure, the government extended a blanket guarantee to all Irish bank liabilities, nationalized a large bank and recapitalized much of the remaining banking system, bringing about partial nationalization. A national asset management company bought distressed real estate assets off bank books, and replaced them with government debt. Irish government debt stock rose from $25 \%$ of GDP in 2007 to nearly $120 \%$ in $2012 .{ }^{49}$ Some estimated the government's contingent liabilities at over $200 \%$ of GDP. ${ }^{50}$ Economic fallout from the crisis would have pushed up Irish government debt in any case; the bank rescue tipped it into dangerous territory. ${ }^{51}$ Even as guarantees expired and bank restructuring proceeded apace, nearly a third of all Irish bank loans were nonperforming in 2012 - by far the highest level in Europe. ${ }^{52}$

1.41 At first, the Irish case was seen primarily as one of bailouts gone wrong. Ireland and Iceland, whose financial systems imploded at about the same time, showed that bank bailouts could sink government finances. Iceland drew the line on guarantees to protect its own; Ireland did not - perhaps could not. In both countries, insolvencies across an outsize banking sector were bound to have a spectacular impact on public finances, even though both countries started with low government debt. In Iceland, the distribution battles between the government and its banks took place largely behind the wall of capital controls. Irish banks remained internationally active, and soon fell victim to the debt problems of the government that saved

\footnotetext{
${ }^{48}$ For theories of transmission between governments and banks, see Viral V. Acharya, Itamar Drechsler, and Philipp Schnabl, A Pyrrhic Victory? Bank Bailouts and Sovereign Credit Risk (Working Paper 17136, National Bureau of Economic Research, June 2011); Patrick Bolton \& Olivier Jeanne, Sovereign Default Risk and Bank Fragility in Financially Integrated Economies, 59 IMF Economic Review 162 (2011). For an empirical investigation, see e.g., Chiara Angeloni \& Guntram B. Wolff, Are banks affected by their holdings of government debt? Bruegel Working Paper 2012/07 (March 26, 2012), available at http://www.bruegel.org/publications/publicationdetail/publication/717-are-banks-affected-by-their-holdings-of-government-debt/. See also Bank for International Settlements, The Impact of Sovereign Credit Risk on Bank Funding Conditions, CGFS Paper No. 43 (2011).

${ }^{49}$ International Monetary Fund, Ireland: Staff Report for the 2012 Article IV Consultation (August 21, 2012) Tbl. 4 at 37, available at http://www.imf.org/external/pubs/ft/scr/2012/cr12264.pdf.

${ }^{50}$ Angelo Baglioni \& Umberto Cherubini, Marking-to-Market Government Guarantees to Financial Systems: An Empirical Analysis of Europe 13 tbl.6 (Preliminary Draft, November 10, 2010) available at http://papers.ssrn.com/sol3/papers.cfm?abstract_id=1715405\&download=yes.

${ }^{51}$ International Monetary Fund, supra note 39; see also Karl Whelan, ELA, Promissory Notes and All That: The Fiscal Costs of Anglo Irish Bank (Revised Draft, September 2012) available at http://www.karlwhelan.com/IrishEconomy/Whelan-PNotes-September2012.pdf.

52 International Monetary Fund, European Union: Publication of Financial Sector Assessment Program Documentation - Technical Note on Progress with Bank Restructuring and Resolution in Europe 14, IMF Country Report 13/67 (March 2013) available at http://www.imf.org/external/pubs/ft/scr/2013/cr1367.pdf.
} 
them. On learning that they had to pay extra to pledge their government debt as collateral for European clearing houses, Irish banks chose instead to dump their sovereign bondst. ${ }^{53}$

1.42 Europe, and Ireland in particular, holds the dubious prize for testing the ultimate implications of bank-government ties. Where neither banks, nor governments, can fully cushion each other's falls; where no fairy godmother materializes with transfers or deep-pocketed creditors from abroad; and where governments are committed to avoid default and maintain open capital flows, the link between banks and governments becomes a suicide pact—or the Doom Loop.

\section{Conclusions}

1.43 The case studies in this essay illustrate some ways in which bank-government links operate in crisis. Three themes recur. First, banks and governments appear to be indispensable partners in one another's crises. The relationship holds with or without "twin" bankgovernment crises, which are rare, and apart from the feedback "doom loop." In particular, bank and government liabilities seem to migrate easily between bank and government books as the crisis deepens, and as part of its resolution. Second and related, private bank balance sheets emerge as public policy conduits. Japan and Korea highlight the fact that this function is not limited to crisis; however, it becomes particularly stark in crisis. Banks sprout new assets and liabilities, which might be valued in brand new ways in the name of financial stability. Third, when banks are internationally active, they come to mediate distribution of losses among governments. Governments want private creditors to bear the consequences of their risk-taking, but feel compelled to shield their own nationals, and try to get other governments to pick up the tab.

1.44 Policy response to this abiding link between banks and governments is a mix of palliative and denial. It starts with a story of the relationship as a symptom of under-development and crisis, one of aberration and redemption. Reforms are then sold as projects for getting banks off government dole and getting governments out of banking — as in the Dodd-Frank Act's promise that taxpayers "shall bear no losses" from bailing out insolvent banks, ${ }^{54}$ and the European banking union's "imperative to break the vicious cycle between banks and sovereigns. ${ }^{" 55}$ Such statements are misleading at best: Dodd-Frank elaborates the process by which governments may support a broader range of financial institutions, while Europe substitutes the regional government for national ones in the bank-government marriage. Both try to limit government support for financial institutions and other governments, and to raise

\footnotetext{
${ }^{53}$ David Oakley \& Sam Jones, Bond Sell-off Takes Ireland Closer to Tipping Point, FINANCIAL TIMES, Nov. 10, 2010, http://www.ft.com/intl/cms/s/0/41815768-ecfa-11df-9912-00144feab49a.html\#axzz2Vk2nkWCR.

${ }^{54} 12$ U.S.C. $\S 5394$ (c) (2010)

${ }^{55}$ Euro Area Summit Statement, Brussels European Council (June 29, 2012).
} 
its price ex ante. This is renegotiation, not divorce - and properly so, since attempts to renounce bailouts by rule have yet to survive a crisis. ${ }^{56}$ Still, there remains the relationship that dare not speak its name.

1.45 Acknowledging the pervasive and enduring nature of bank-government ties reframes the policy task. Instead of outlawing bailouts, the focus shifts to the precise terms of loss-sharing between banks and governments, and among governments, in crisis - and the incentive effects of this allocation in good times. Decisions about the terms of the bargain must be intelligible to the public and democratically accountable, if only because of their enormous consequences for distribution, in good times and bad. The democratic imperative in turn raises a host of research and policy questions. For example, to what extent should government promises of support for banks - and banks' tacit backing of governments-be made explicit on bank and government balance sheets? Should bank and government claims on one another occupy a special place in the claims hierarchy — and if yes, what should that place be? Should regulatory privileges for government debt be abolished — or made more explicit and institutionalized? Considering the limits on the enforcement of government promises (amply demonstrated elsewhere in this volume), what is the right commitment device to ensure that governments deliver on their promises of debt repayment, liquidity support, and recapitalization - and that banks pay a fair price for the benefits they receive? How might government commitments to one another (for example, to share losses in crossborder bank resolution) fare in such a newly transparent regime? And how might the answers to such questions affect the structure of the financial sector, and the behavior of banks and governments going forward?

1.46 The answers are far beyond the scope of this essay. For now, describing the bankgovernment relationship with its cross-border dimensions as something other than an aberration to be stamped out or swept under the rug might prompt a more humble look at crisis management and regulation. Reforming the relationship to limit its worst dysfunctions, and to render it intelligible and accountable to the public in whose name it exists, will take more than official declarations. Harnessing its stabilizing potential is an even bigger challenge. "Walking back from Cyprus" will take a while — and, on the bright side, many more drafts in Arial 12.

\footnotetext{
${ }^{56}$ See Consolidated Version of the Treaty on the Functioning of the European Union art. 123, 125, Mar. 30, 2010, 2010 O.J. (C 83) 99. See also Jonathan Tomkin, Contradiction, Circumvention, and Conceptual Gymnastics: The Impact of the Adoption of the ESM Treaty on the State of European Democracy 14 Ger. L.J. 169, 180-81 (explaining how articles 123-25 of the Lisbon Treaty have been functionally abandoned); Adam Levitin, In Defense of Bailouts, 99 GEO. L.J. 435, 299 (2011) (explaining how governments have generally ignored the law when engaging in lenderof-last-resort activity); id. at 487 (explaining how bankruptcy can be a "procedure" for a bailout). But cf. John B. Taylor, Preface to John B. TAYLOR \& KenNeth E. SCOTt, BANKRUPTCY Not BAILOUt, at ix, ix-xii (2012) (proposing to replace bailouts with a new bankruptcy mechanism).
} 